\title{
P.Oxy. 2174 fr. 5: an Odyssey for Hipponax?
}

\author{
Enrico Emanuele Prodi *
}

\begin{abstract}
This article re-examines P.Oxy. 2174 fr. 5 (Hipponax fr. 74 West = Degani), offers an improved transcription of its text, and questions its relevance to the other fragments of the papyrus, suggesting instead that it may belong to a papyrus of the Odyssey.
\end{abstract}

Keywords: P.Oxy. 2174, Hipponax, Homer, Odyssey

DOI 10.1515/apf-2017-0001

In the preface to his edition of P.Oxy. XVIII 2174 and 2175 ('Hipponax, Iamboi'), Edgar Lobel wrote: 'It is allowable to recognize in $\mathbf{2 1 7 4}$ frr. 5, $6,8,9$, the title and some of the details of a 'Return of Odysseus' - seaweed, after a snack questions about family, Phaeacians, the lotus, perhaps a dreadful giant, an auger, embers, not to mention more problematic indications - to which the extant frr. 21 Knox [51 West = 54 Degani] and 91 Knox $[129 \mathrm{~W} .=127 \mathrm{Dg}$.$] ... may also be related'. { }^{1}$ The presence in

\footnotetext{
* Kontakt: Enrico Emanuele Prodi, Dipartimento di Studi Umanistici, Università Ca' Foscari, Dorsoduro 3848/D, I-30123 Venezia, <enricoemanuele.prodi@unive.it>

${ }^{1}$ The Oxyrhynchus Papyri XVIII (1941), 67. P.Oxy. 2174 is MP ${ }^{3}$ 547, LDAB 1316, TM 60199. I am grateful to Vanessa Cazzato, Ettore Cingano, Daniela Colomo, and Giuseppe Ucciardello for fruitful discussions of the topic. I have examined the original at the Sackler Library in Oxford. All images are published courtesy of the Egypt Exploration Society and Imaging Papyri Project, Oxford and are (C) The Egypt Exploration Society. This project has received funding from the European Union's Horizon 2020 research and innovation programme under Marie Skłodowska-Curie grant agreement No 708556.
} 
2174 of several details that remind one of the Odyssey is above doubt. The title preserved by fr. 5 (fr. $74 \mathrm{~W} .=$ Dg.), however, deserves more attention than it has received so far. Lobel evidently regarded it as the title of a poem, and this is the interpretation that most subsequent editors have accepted. ${ }^{2}$ The only scholar to date who has engaged with fr. 5 in greater detail is Margarita Alexandrou, who has refined the consensus position while insightfully exploring its implications for the poem and its performance. ${ }^{3}$ But the relevance of the title to the poetry of Hipponax requires further scrutiny. Let us examine the evidence (Figure 1).

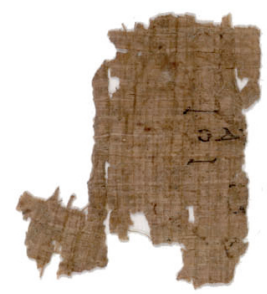

Figure 1

First, the hand. Not much can be said of it, but it is clearly not the same as the one that copied the rest of the papyrus. Not only is it slightly smaller; it also writes in a distinctly different script, so much so that none of the three clearly preserved letters matches in shape the numerous occurrences of the same letters in the other fragments. The pen too seems to be different: sharper and finer. ${ }^{4}$

Second, the text. Lobel prints it as follows: ${ }^{5}$

\footnotetext{
${ }^{2}$ W. de Sousa Medeiros, Hipónax de Efeso I (Coimbra 1961), 114-15; O. Masson, Les fragments du poète Hipponax (Études et commentaires XLIII, Paris 1962), 70, 143; M.L. West, Iambi et elegi Graeci ante Alexandrum cantati I (Oxonii 1989²), 130; F.R. Adrados, Líricos griegos. Elegiacos y yambógrafos arcaicos II (Madrid 1990²), 44; H. Degani, Hipponactis testimonia et fragmenta (Stutgardiae et Lipsiae 1991²), 89; D.E. Gerber, Greek Iambic Poetry (Cambridge MA/London 1999), 411. See also the works cited at n. 22 .

3 'Mythological narratives in Hipponax', in L. Swift and C. Carey (eds), Iambus and Elegy. New Approaches (Oxford 2016), 218-20.

${ }^{4}$ I owe this point to Daniela Colomo.

${ }^{5}$ Cit. n. 1, 70 .
} 
Fr. 5 .
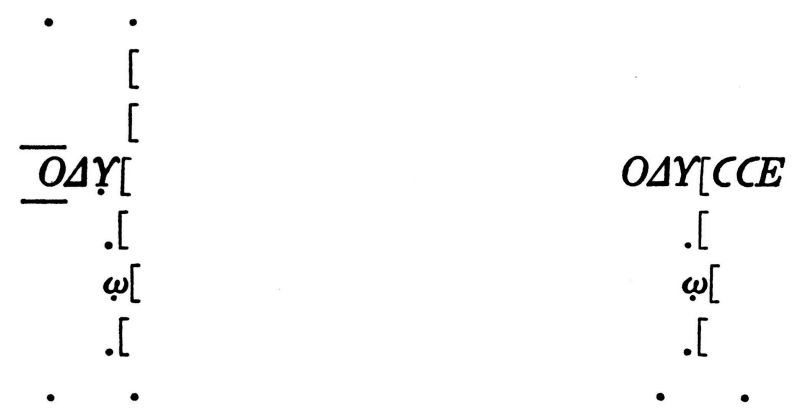

The first line is correct: o $\delta v$ [ it is, with $v$ all but certain and o adorned by serifed horizontals above and below. The extant traces of the supposed second and fourth lines, however, do not suggest 'The base-line of a letter like $\delta, \zeta$ ' and 'A stroke sloping upwards from line-level, left to right' (Lobel) as much as another pair of serifed horizontals, of the lower of which only the serif survives. The distance between them is slightly higher (just under $6 \mathrm{~mm}$ ) than between those encompassing the first line $(5 \mathrm{~mm})$, but the difference is negligible in a handwritten text. This suggests, then, that the supposed third line is not the second line of the text that followed the title, but the second line of the title itself, ornamented in the same way as the first. Of the lone surviving letter of that line Lobel writes, 'Of $\omega$ only the central apex'. I wonder: where the loop on the left would have been, no trace of ink is visible, and the horizontals above and below o in the first line protrude on either side of it by just over a millimetre, while here they would be flush with the supposed $\omega$. Given this, one might read the surviving trace - which looks much like a small reversed $\mathrm{V}$ with slightly convex arms - as either a letter on its own right $(\lambda$ ?) or the left part of one ( $\mu$ ? Neither of these is compelling, but $\omega$ seems even less so).

Third, the position. The writing below odv [ is not matched by writing above it. Consequently, if the writing below odv [ is taken as three verses, the fragment must originally have stood at the top of a column, as Alexandrou notes ${ }^{6}$ fr. 1 (Figure 2) proves that poems were not separated from one another by wide blanks, as sometimes they are in other manuscripts. If conversely what we have is not title and three verses, but a title split over two lines and no verses, we have more flexibility on the

\footnotetext{
${ }^{6}$ Alexandrou, cit. n. 3, 218 n. 37.
} 
exact placement of the fragment - until, that is, we take stock of the evidence for poem-titles in Hipponax, on the one hand, and in the papyrological record, on the other.

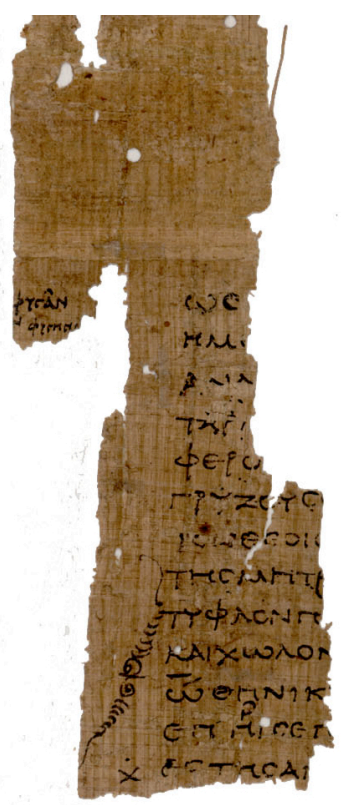

Figure 2

The evidence for poem-titles in Hipponax is slim at best. The indirect tradition offers no proof of their existence: Tzetz. in Lyc. 219 p. 102

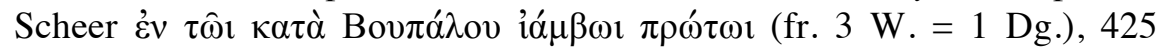

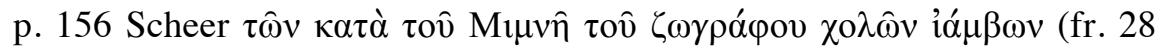

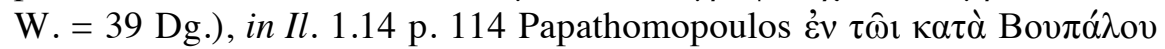

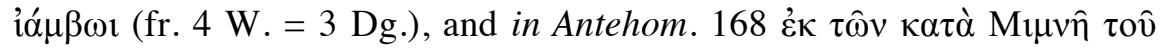
$\zeta \omega \gamma \rho \alpha ́ \varphi$ ov $\chi \omega \lambda \iota \alpha \dot{\alpha} \mu \beta \omega v$ (again fr. $28 \mathrm{~W} .=39 \mathrm{Dg}.)^{7}$ need not have anything to do with actual titles, much less with ancient ones. ${ }^{8}$ In the papyri there is no clear example of a poem being provided with a title (it is doubtful whether the marginal annotation on P.Strassb. $3 \mathrm{fr} .1$ is even compatible with

\footnotetext{
${ }^{7}$ Text from Degani, cit. n. 2, 54 .

${ }^{8}$ Rightly Alexandrou, cit. n. 3, 219 n. 39 - 'an informal way of distinguishing thematically between the various abusive poems against several enemies in the corpus' - against E. Degani, Studi su Ipponatte (Bari 1984), 235 and n. 29, and id., cit. n. 2, 23.
} 
interpretation as a title $)^{9}$ versus one clear example of the contrary, P.Oxy. 2174 fr. 1. Things are no different with Archilochus. In the surviving papyri of his poetry the division between consecutive poems is preserved at least seven times, probably eight, and possibly nine; the two possible poem-titles (P.Oxy. XXII 2310 fr. 1 and P.Petrie I 4 (2) = P.Lond.Lit. 55, both highly uncertain $)^{10}$ are offset by six to eight instances in which it can be verified that no title is present: P.Oxy. 2310 fr. 1 (probably twice) and XXII 2312 fr. 24, from the Trimeters; P.Oxy. VI 854 and LXIX 4708 frr. 3, 8 (twice), from the Elegies; perhaps P.Oxy. XXII 2314, from the Tetrameters. Outside iambos, different authors are treated differently from each other but - it seems - consistently within themselves. In the papyri, the poems of Simonides, Bacchylides, and Pindar are systematically introduced by titles, at least from the beginnings of the Roman period and quite possibly earlier; those of Sappho, Alcaeus, or Anacreon never are. ${ }^{11} \mathrm{Com}-$ parable authors whose individual poems were sometimes introduced by titles, sometimes not, in their respective 'standard' editions are precious few: perhaps Archilochus, perhaps not even he.

${ }^{9}$ For the status quaestionis see A. Nicolosi, Ipponatte, Epodi di Strasburgo. Archiloco, Epodi di Colonia (con un'appendice su P.Oxy. LXIX 4708) (Eikasmos studi 14, Bologna 2007), 36-7, 101-2, with earlier bibliography.

${ }^{10}$ In P.Oxy. 2310 fr. 1 the line in question, col. i. 40 ] . . (the first letter can be o or c, the second c or perhaps v; E. Lobel, The Oxyrhynchus Papyri XXII (1954), 4-5 prints the second as a high stop, but this is palaeographically dubious as well as unexpected in a heading), is shorter than the verses above and below it, and cannot be an iambic trimeter, but what it actually is is debatable: it may have been a poem-title, or a section-heading, or perhaps even an indication of authorship ('A $\rho \chi 1 \lambda o ́ \chi]$ ọ) if P.Oxy. 2310 was a miscellany, as suggested by A. Colonna, 'Adnotationes ad papyrum Oxy. 2310, 1', BENC n.s. 7 (1959), 51-3. As for P.Lond. Lit. 55, the suggestion that a few letters to the left of col. ii.19-21 may represent a title was made by E.G. Turner ap. F. Lasserre and A. Bonnard, Archiloque. Fragments (Paris 1958), lxxi and n. 2, but it is not very plausible; West, cit. n. 2, 35, cited with approval by A. Porro, CLGP I.1.3 (2011) 165, regards them as part of the poetic text in col. $\mathrm{i}$, as indeed is suggested by their position.

${ }^{11}$ Alcman, Stesichorus, and Ibycus cannot be brought to bear on this topic. The extant fragments of Alcman and Ibycus provide no evidence on whether their poems had titles or not. With Stesichorus we have no evidence that any of his poems were of less than book length (the Geryoneid was at least a whole book long, as strongly suggested by the stichometric letter indicating line 1,300 on P.Oxy. XXXII 2617 fr. 25; the (Trojan?) Horse

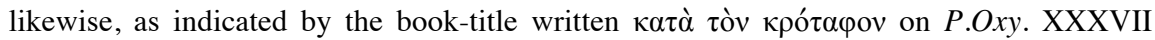
2803 fr. 1; the Helen and the Oresteia comprised at least two books each, as implied by arg. Theocr. 18 p. 331 Wendel, $\Sigma^{\mathrm{V}}$ D.T. p. 183 Hilgard, P.Oxy. VIII 1087 col. ii, and epit. Hdn. fr. 5 Hunger), so if we are dealing with poem-titles as opposed to book-titles, his known titles belong in the latter category, not in the former. 
Furthermore, the extant poem-titles on the papyri of Simonides, Pindar, and Bacchylides do not look much like the one on P.Oxy. 2174 fr. 5. Such titles survive in at least 19 papyri (representing 21 or 22 manuscripts) across the three authors. ${ }^{12}$ They are either inset in the column and written by the same hand as the poetic text, sometimes in eisthesis and sometimes with a little extra space above and/or below; or written in the margin either by the scribe himself or by a second hand. In the surviving record they are never written in the column by a second hand. Ornamentation is also exceedingly scarce. The latest and sorriest papyrus of the lot, P.Oxy. XIII 1614 (a fifth- or sixth-century codex containing Pindar's Olympians), has the title of $O .2$ sandwiched between two rows of ornamental signs; in a manuscript of Pindar's Paeans, P.Oxy. LVI 3822, the two partly extant titles (frr. 1,5) have the first and last letter of each word ornamented by a dot above and one below - so discreet an adornment that the first editor did not even mention it. Somewhat ornamental are also the enlarged letters of the title in PSI X 1181 (assigned with some likelihood to Bacchylides' Dithyrambs) and the two asteriskoi that grace either side of it. ${ }^{13}$ All four of these titles are inset in the column and written by the main scribe; there appears to be no published example of ornamentation added to a marginal title in any of our three authors.

The title in P.Oxy. $2174 \mathrm{fr} .5$ is certainly not marginal. We can measure the width of the intercolumnium in fr. 11 (min. $11 \mathrm{~mm}$, max. $19 \mathrm{~mm}$ ); the datum is roughly confirmed by frr. 1 and 16, where col. i is lost but two marginal annotations are preserved to its right, and by fr. 22, where col. ii is lost but two chi signs are preserved to its left. There is no way that our title and its leisurely left margin could fit. Is it inset and at the top of a column? Possibly. While splitting a title into more than one line is (logically) more frequent with marginal than with inset titles, there are a few

\footnotetext{
${ }^{12}$ For the dataset and a tentative analysis see E.E. Prodi, 'Titles and markers of poemend in the papyri of Greek choral lyric', in T. Derda, A. Łajtar, and J. Urbanik (eds), Proceedings of the XXVII International Congress of Papyrology (Warsaw 2016), 1137-84. The mismatch between papyri and manuscripts is due to P.Oxy. XXV 2430 of Simonides, probably representing two manuscripts; XXVI 2442 of Pindar, representing at least three manuscripts (in only two of which any titles survive); and P.Lond.Lit. 46 of Bacchylides, which may represent either a single manuscript, as affirmed by J. Irigoin, most recently in Bacchylide. Dithyrambes - Épinicies - Fragments (Paris 1993), xxviii-xxxi, or two, as suggested by F. Blass, Bacchylidis carmina cum fragmentis (Lipsiae $1898^{1}$ ), iv-vii, and accepted by subsequent Teubner editors.

${ }^{13}$ On these asteriskoi see already G. Nocchi Macedo, 'Formes et fonctions de l'astérisque dans les papyrus littéraires grecs et latins', $S \& T 9$ (2011), 20.
} 
possible parallels: P.Oxy. XXV 2431 fr. 1 (unless the first line is a sectionheading), ${ }^{14}$ PSI II 147 fr. VI ${ }^{\mathrm{V}}$ (unless the second line is a subtitle of sorts). ${ }^{15}$ But some doubt remains. A heavily ornamented poem-title is uncommon; a poem-title in Hipponax is unexpected (although there may have been grounds for an exception in this particular case, as Alexandrou has illustrated); ${ }^{16}$ and an inset title written by a different hand from the poetic text is unparalleled in the papyri that are generically closest to ours.

So our title does not look much like poem-titles in the papyri of comparable poets. However, there is another kind of titles to which conversely it bears a clear resemblance: namely, book-titles. At least from the beginnings of the Roman era these were regularly written at the end (less frequently also at the beginning) of the book-roll. ${ }^{17}$ End-titles are normally placed either in the blank space below the last column of the text, or in the agraphon that follows it; that is, in either case, at some distance from the text in all directions. Often they are split over multiple lines. Also often they are ornamented in some way, such as with concave or horizontal lines above and below them..$^{18}$ As it happens, such lines placed above and below the first and last letter of each word are a particular favourite. As examples similar to our fragment one can cite P.Oxy. III 412 (Julius Africanus, Kestoi book 18), V 843 (Plato, Symposium), X 1231 fr. 56 (Sappho book 1), XVII 2076 (Sappho book 2), XLV 3209 fr. 1 (Alcman book 6),

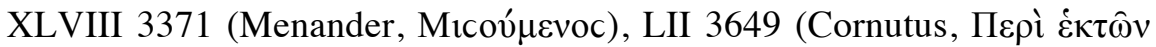
book 2) and 3683 ('Plato', Alcyon), LIII 3715 (Euripides, Phoenissae),

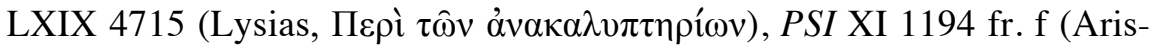

${ }^{14}$ So G.B. D'Alessio, 'Pindar's Prosodia and the classification of Pindaric papyrus fragments', ZPE 118 (1997), 53 n. 175.

${ }_{15}^{15}$ So G. Vitelli, Papiri greci e latini II (1913), 77.

${ }^{16}$ Alexandrou, cit. n. 3, 219.

${ }^{17}$ A complete repertory of end-titles found in Greek papyri has yet to be compiled, but

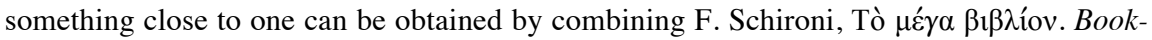
ends, End-titles, and Coronides in Papyri with Hexametric Poetry (ASP 48, Durham NC 2010) (with a list of end-titles in non-hexameter papyri at pp. 228-38) with G. Del Mastro, Titoli e annotazioni bibliologiche nei papiri greci di Ercolano (Napoli 2014). See also the rich introduction of M. Caroli, Il titolo iniziale nel rotolo librario greco-egizio (Bari 2007), and P. Fioretti, 'Sul paratesto nel libro manoscritto (con qualche riflessione sui 'titoli' in età antica)', in L. Del Corso, F. De Vivo, and A. Stramaglia (eds), Nel segno del testo. Edizioni, materiali e studi per Oronzo Pecere (Papyrologica Florentina XLIV, Firenze 2015), 179-202.

${ }^{18}$ On ornamentation in end-titles of hexameter papyri see Schironi, cit. n. 17, 23-4, 215-17; in papyri from Herculaneum, Del Mastro, cit. n. 18, 18-20. 
tophanes, Thesmophoriazusae), and many of the hexameter papyri and of the Herculaneum rolls whose end-titles have been studied respectively by Francesca Schironi and Gianluca Del Mastro. ${ }^{19}$

What to make of our fragment, then? The layout would suit an end-title very well. Consequently, one could perhaps suggest that Ody[ss- (Odysseus? Odyssey? Odysseus' Something-or-Other, perhaps Return as suggested by Lobel? Odysseus among the Phaeacians as suggested by Enzo Degani? $)^{20}$ was the title not of a single poem, but of an entire book of Hipponax, taking to an extreme Alexandrou's argument that 'the poem carrying the title was in some respects distinct from the rest of the Hipponactean material' ${ }^{21}$ This would not entail a major reframing of current interpretations of the poet, given the many echoes of the Odysseus myth that have long been recognised here and there in his verses,${ }^{22}$ but it would set this feature of his poetry on a much larger scale than anyone would have dared to imagine. There are three obstacles, however. The first is the hand: end-titles are normally written by the same scribe as the main text, even though (rare) exceptions are attested..$^{23}$ More importantly, no ancient source suggests that Hipponax's books had individual titles. Whenever a reference is given, it is invariably by number: 'in the first book', 'in the second book'. ${ }^{24}$ The third and greatest obstacle is posed by a banal biblio-

${ }^{19}$ See n. 17.

${ }^{20}$ Ipponatte. Frammenti (Eikasmos studi 15, Bologna 2007), 116.

${ }^{21}$ Alexandrou, cit. n. 3, 219.

${ }^{22}$ See for instance J. Pòrtulas in id. and C. Miralles, The Poetry of Hipponax (Roma 1988), 77-83; R.M. Rosen, 'Hipponax and the Homeric Odysseus', Eikasmos 1 (1990), 11-25; M. Steinrück, Iambos. Studien zum Publikum einer Gattung in der frühgriechischen Literatur (Spudasmata 79, Zürich/New York 2000), 90-2; C. Carey, 'Hipponax narrator', AAntHung 48 (2008), 95, 97-8; V. Cazzato, 'Hipponax' poetic initiation and Herodas' 'Dream', CCJ 61 (2015), 11-12; M. Alexandrou, cit. n. 3, 211-18; ead., 'Hipponax and the Odyssey. Subverting text and intertext', in A. Efstathiou and I. Karamanou (eds), Homeric Receptions across Generic and Cultural Contexts (TiC suppl. 37, Berlin/Boston 2016), 31-44; T. Hawkins, 'Bupalus in Scheria: Hipponax's Odyssean transcontextualizations', in Swift and Carey, cit. n. 3, 229-52. Contrast the caution of A. Farina, Ipponatte (Napoli 1963), 148-9, and the scepticism of M.L. West, Studies in Greek Elegy and Iambus (ULG 14, Berlin/New York 1974), 30.

${ }^{23}$ One likely example is the recently published hypomnema to Archilochus' Trimeters, P.Oxy. LXXIII 4952. At Herculaneum, titles written by a hand different from the main scribe's are also attested, although again rarely: Del Mastro, cit. n. 17, 16-17.

${ }^{24}$ There are, however, rare cases in which a book has both an individual title and an ordinal number within a larger whole: e.g. book 3 of Pindar's Partheneia, which was also

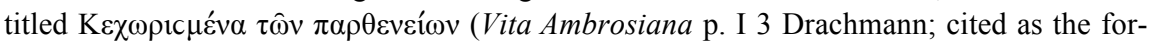


logical consideration. Just like modern book covers, ancient end-titles normally indicated not only the title of a work, but also its author, in the genitive, usually before the title itself. ${ }^{25}$ And there is no author's name in

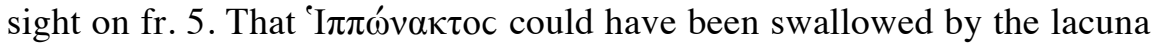
is unlikely: it is not a short word, so it is difficult to imagine what title certainly not Odysseus or Odyssey - could have been so long as to protrude by some distance on either side of the putative 'I $\pi \pi \omega$ voк $\tau$ oc in each of the two lines over which the title was split. ${ }^{26}$

A possible way out is that his name was simply not indicated. The omission of the author's name from an end-title is rare, but not unattested: Sappho's name is not written on P.Oxy. X $1231 \mathrm{fr} .56$ ( $\mu \varepsilon \lambda \hat{\omega} v \bar{\alpha}$, followed by a stichometric count). ${ }^{27}$ But another possibility beckons to be explored. The rule that end-titles preface the title of the work with the name of its author has one constant exception: Homer ${ }^{28}$ What a suspicious coincidence it is that the title of one of his major works begins, precisely, with

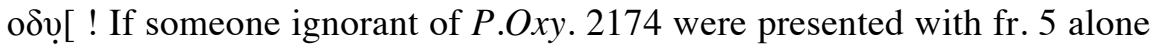
and tasked with editing it, the most intuitive supplement would certainly

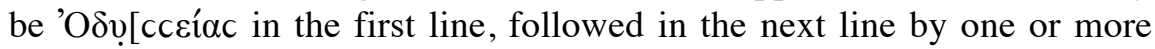
letters indicating the individual book(s) which the roll contained. ${ }^{29}$ The question then is: how far, if at all, does P.Oxy. 2174 as a whole shift the balance away from this hypothesis?

Pieces of different papyri can and do end up being mixed together, and often a fragment edited with one papyrus proves to belong with another:

mer by P.Oxy. XXVI 2438 col. ii. 37, as the latter by $\Sigma$ ap. P.Oxy. 2438, $\Sigma$ Pind. Pyth. 3. 139a p. II 81 Drachmann, and $\Sigma$ Theocr. 2.10 b p. 271 Wendel).

${ }^{25}$ Caroli, cit. n. 17, 63-6; Schironi, cit. n. 17, 63-5, 79.

${ }^{26}$ The point on the length of the title is also made by Alexandrou, cit. n. 3, 219 n. 38, although on different assumptions.

${ }^{27}$ Schironi, cit. n. 17, 63-8, discusses the several papyri of Attic orators which mark the end of a speech with only its title, and not the name of its author, but arguably the end of an individual speech within a (single-author) roll is a different matter from the end of the entire roll. She suggests that P.Oxy. 1231 may likewise have contained more than one book of Sappho, but her hypothesis is not confirmed by the surviving fragments.

${ }^{28}$ Caroli, cit. n. 17, 65-6; Schironi, cit. n. 17, 22-3, 63. See now the interpretation proposed by E. Castelli, 'Omero e il paratesto. Sulla proprietà letteraria nel mondo greco e una irrisolta questione dei papiri dell'Iliade e dell'Odissea', ZPE 201 (2017) 1-11.

${ }^{29}$ An end-title indicating more than one book is found in P.Lond. Lit. 5 (the 'Harris Homer codex', Iliad books 1-6). Conversely, book-final titles in P.Amh. inv. G 202 (the 'Morgan Homer', Iliad 11-16) occasionally duplicate the letter denoting an individual book. These are both codices, but multi-book rolls of Homer are well attested (see Schironi, cit. n. 17, 210-11), and roll-final titles may well have behaved in a similar way. 
one need only cite the spectacular recent cases of P.Oxy. LXIV 4411, which turned out to consist of three different manuscripts (the anonymous piece of Old Comedy to which it was originally ascribed, a book of Sappho, and Plato's Critias) ${ }^{30}$ and of the four fragments alleged to come from Hesiod's Catalogue of Women which proved instead to be Plutarch, Homer, and Demosthenes. ${ }^{31}$ Lobel makes no mention of any of the problems raised by fr. 5 - not even of the fact of the different hand - nor does he lay out his reasons for taking the fragment together with the rest of P.Oxy. 2174. It is hard to imagine him, of all papyrologists, having anything other than a very good reason to do so. However, in the absence of excavation and conservation records, we cannot even be certain that fr. 5 was found together with the other fragments. From the physical point of view, nothing connects fr. 5 with the rest of the papyrus. The strongest element on which one normally relies to draw such connections - the hand - is evidently different. All this being the case, that fr. 5 belongs with P.Oxy. 2174 can no longer be assumed without argument. The hypothesis of an intrusive fragment - perhaps the end-title of a book-roll of the Odyssey - deserves serious consideration.

${ }^{30}$ Sappho: M. Steinrück, 'Neues zu Sappho', ZPE 131 (2000) 10-12, see also id., 'Sappho und die Wahrheit', QUCC 94 (2010), 79-87, and L. Prauscello and G. Ucciardello, 'Sappho 88 Voigt (P.Oxy. 2290 + P.Oxy. 4411): a re-appraisal', ZPE 195 (2015) 1329. Plato: L. Prauscello and G. Ucciardello, 'Hands and book-rolls in P.Oxy. 4411: the first extant papyrus witness for Plato's Critias (P.Oxy. 4411, frr. 88-90+92+94-95)', ZPE 191 (2014), 47-58.

${ }^{31}$ P.Oxy. XXVIII 2481 frr. 6, 7 = Plu. Quaest. Conv. 4.1.2, 3; P.Oxy. XXVIII 2495 fr. 5 = Od. 16.356-61; PSI XIV 1384 fr. 2 = D. 57.3. See D. Danbeck, 'Four formerly Hesiodic fragments', ZPE 187 (2013), 31-4. 